\title{
ZRSR2 Gene Mutation
}

National Cancer Institute

\section{Source}

National Cancer Institute. ZRSR2 Gene Mutation. NCI Thesaurus. Code C133701.

A change in the nucleotide sequence of the ZRSR2 gene. 